\title{
Lama Perendaman Ekstrak Pucuk Daun Ungu Terhadap Tegangan Yang Dihasilkan DSSC
}

\author{
Komang Alit Kumara Jaya ${ }^{1)^{\star}}$, I Gusti Ngurah Nitya Santiarsa ${ }^{2)}$, I Ketut Suarsana ${ }^{3)}$ \\ ${ }^{1)}$ Program Studi Magister Teknik Mesin, Fakultas Teknik, Universitas Udayana \\ Gedung Pascasarjana, Universitas Udayana Sudirman, Bali 80113 \\ Email: alitkumarajaya@yahoo.com \\ ${ }^{2,3)}$ Jurusan Teknik Mesin, Fakultas Teknik, Universitas Udayana \\ Bukit Jimbaran, Bali 80362 \\ Email: santhiarsa@yahoo.com, ktsuarsana@yahoo.com
}

doi: https://doi.org/10.24843/METTEK.2020.v06.i01.p03

\begin{abstract}
Abstrak
Pada umumnya masyarakat di Indonesia masih menggunakan sumber energi tidak terbaharui yang suatu saat akan habis. Penggunaan energi meningkat pesat sejalan dengan pertumbuhan ekonomi dan pertumbuhan penduduk, energi surya merupakan energi yang memiliki potensi besar. Dye sensitized solar cell (DSSC) merupakan solar cell generasi ke 3. Daun ungu merupakan tumbuhan yang tersebar hampir di seluruh Indonesia, mudah dibudidayakan dan tidak merupakan daun dengan nilai ekonomi tinggi juga tidak kenal musim dalam tumbuh kembangnya. Penelitian ini menggunakan ekstrak pucuk daun ungu sebagai dye sensitizer di ekstrak menggunakan alkohol (96\%) dengan perbandingan campuran $20 \mathrm{gr}$ pucuk daun ungu yang sudah ditumbuk halus dengan alkohol sebanyak $50 \mathrm{ml}$, kemudian direndam dengan variasi lama perendaman 12, 24 dan 36 jam. Penelitian ini bertujuan untuk mengetahui pengaruh lama perendaman terhadap tegangan yang dihasilkan DSSC. Hasil penelitian didapat hasil tegangan tertinggi pada variasi lama perendaman 36 jam sebesar $254 \mathrm{mV}$. Lama perendaman 12 jam sebesar $202 \mathrm{mV}$ dan lama perendaman 24 jam berada diantara kedua variasi tersebut dengan nilai tegangan dan arus sebesar $230 \mathrm{mV}$.
\end{abstract}

Kata kunci: Dye sensitized solar cell, pucuk daun ungu, lama perendaman

\begin{abstract}
Generally people in Indonesia still use non-renewable energy sources that will one day be exhausted. Energy use in Indonesia increased considerably in line with economic growth and population growth, solar energy is the energy that has great potential. Dye sensitized solar cells (DSSC) are 3rd generation solar cells. Purple leaf is a plant that is spread almost all over Indonesia, easily cultivated and is not a leaf with high economic value nor does it know the season of growth and development. This study uses purple leaf shoot extract as a dye sensitizer extracted using alcohol (96\%) with a ratio of 20 gr of mixture of purple leaf buds that have been finely ground with alcohol as much as $50 \mathrm{ml}$, then soaked with a 12, 24 and 36 hour soaking variation. This study aims to determine the effect of immersion duration on the voltage generated by DSSC. The results obtained the highest voltage at 36 hours soaking variation of $254 \mathrm{mV}$. The 12 hour soaking time is $202 \mathrm{mV}$ and the 24 hour soaking is between the two variations with voltage and current values of $230 \mathrm{mV}$.
\end{abstract}

Keywords: Dye sensitized solar cell, purple leaf buds, soaking variation.

Penulis korespondensi,

Email: alitkumarajaya@yahoo.com 


\section{PENDAHULUAN}

Energi merupakan bagian penting dalam kehidupan masyarakat karena hampir semua aktivitas manusia selalu membutuhkan energi. Misalnya untuk penerangan, proses industri atau untuk menggerakkan peralatan rumah tangga diperlukan energi listrik, serta masih banyak peralatan di sekitar kehidupan manusia yang memerlukan energi. Sebagian besar energi yang digunakan di Indonesia berasal dari energi fosil yang berbentuk minyak bumi dan gas bumi. Keterbatasan energi listrik berbasis fosil sudah mulai mengkhawatirkan, karena selain tidak terbarukan, juga polutif terhadap kemurnian udara. Negara maju sudah mulai banyak melirik clean energy sebagai energi terbarukan, salah satunya energi dari sinar matahari yang merupakan sumber "tidak terbatas" dan berkelanjutan. Dye sensitized solar cell (DSSC) merupakan terobosan baru dalam solar cell. Daun ungu merupakan tumbuhan yang tersebar hampir diseluruh Indonesia, mudah dibudidayakan dan tidak merupakan daun dengan nilai ekonomi tinggi juga tidak kenal musim dalam tumbuh kembangnya. Penelitian [Hardeli (2013)] mengenai bayam merah sebagai dye organik yang lama perendamannya 24 jam, merupakan acuan bahwa selain buah dan bunga, daun juga bisa digunakan sebagai dye sensitizer, namun bayam merah merupakan bahan pangan yang mempunyai nilai ekonomi tinggi, oleh sebab itu pada penelitian ini digunakan daun ungu yang mempunyai nilai ekonomi rendah dan mudah dibudidayakan dengan tujuan yang sama yaitu mampu menghasilkan tegangan listrik seperti yang diharapkan dan tidak menggunakan bahan pangan sebagai dye sensitizer.

\section{METODE}

\subsection{Prosedur Penelitian}

Proses pembuatan ekstraksi pucuk daun ungu yang pertama ditumbuk sampai halus dengan menggunakan mortar dan ditimbang supaya mendapatkan berat 20 gram untuk masing - masing pelarut pada variasi lama perendaman (12, 24, 36 jam). Pucuk daun ungu yang sudah dihaluskan dan ditimbang tersebut kemudian dicampurkan dengan pelarut (alkohol) masing masing tiap variasi sebanyak $50 \mathrm{ml}$. Setelah masing - masing dari ketiga pelarut sudah dicampurkan dengan pucuk daun ungu yang sudah halus, kemudian didiamkan dengan variasi lama perendaman $(12,24,36$ jam) pada ruangan tertutup. Masing - masing dari ketiga ekstrak tersebut disaring menggunakan kertas saring yang nantinya ketiga ekstrak tersebut akan digunakan sebagai natural dyes untuk DSSC yang sebelumnya telah dilakukan pengujian absorbansi ekstrak dengan spectrophotometer $u v$-vis pada rentang panjang gelombang 200 $800 \mathrm{~nm}$.

Pembuatan sandwich DSSC dimulai dari persiapan bahan - bahan (ekstraksi, kaca ITO, TiO2 nanopori, elektrolit, pensil $8 \mathrm{~B}$ ) dan bahan penunjang lain. Dimulai dari pembuatan pasta TiO2 dengan mencampurkan 5 gr TiO2 dengan 1 gr polivinil alkohol (PVA) lalu diaduk pada $80{ }^{\circ} \mathrm{C}$ dan digerus dengan mortar. Pasta $\mathrm{TiO} 2$ kemudian dideposisikan diatas area yang telah ditentukan dengan bantuan scotch tape yang berukuran $2 \mathrm{~cm} \times 2 \mathrm{~cm}$ pada permukaan kaca ITO dengan metode doctor blade dengan bantuan batang pengaduk (spatula) untuk meratakan pasta $\mathrm{TiO} 2$, kemudian didiamkan selama kurang lebih 10 menit, setelah itu dipanaskan diatas permukaan hot plate sampai $300{ }^{\circ} \mathrm{C}$ selama sekitar 20 menit. 


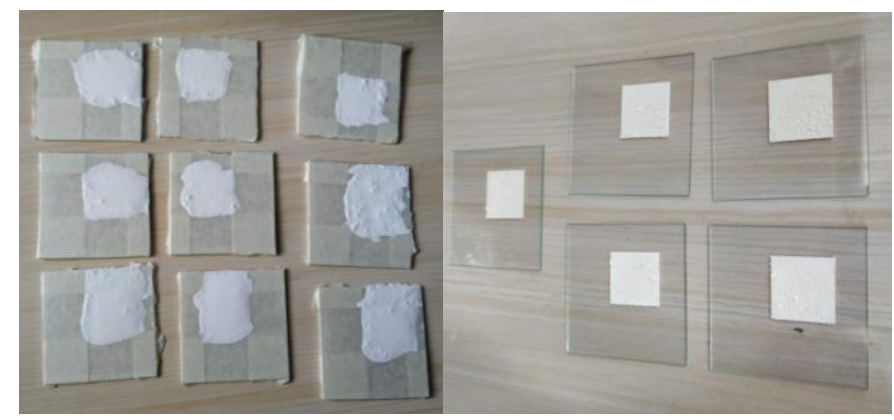

Gambar 1. Proses deposisi pasta $\mathrm{TiO} 2$

Lapisan $\mathrm{TiO} 2$ yang telah dibuat dengan luas permukaan $2 \mathrm{~cm} \times 2 \mathrm{~cm}$ tersebut kemudian direndam pada ekstrak dye pucuk daun ungu, perendaman dilakukan selama 24 jam. Elektrolit dibuat dari campuran kalium iodide (KI) 6 gr dengan iodine solution 5\% $3 \mathrm{ml}$ yang kemudian diaduk selama 20 menit kemudian disimpan pada botol tertutup rapat, langkah awal pembuatan elektrolit fasa gel adalah melarutkan bahan polimer PEG 1000 2,5 gr dengan pelarut chloroform $5 \mathrm{ml}$ diaduk selama 20 menit pada suhu $85{ }^{\circ} \mathrm{C}$, kemudian electrolyte gel yang sudah jadi kemudian disimpan dalam wadah tertutup rapat. Katalis menggunakan pensil 8B yang diarsir diatas permukaan kaca ITO dengan luas permukaan $2 \mathrm{~cm}$ x $2 \mathrm{~cm}$, kemudian dipanaskan menggunakan api lilin untuk mendapatkan lapisan karbon dan dipanaskan lagi diatas hot plate sampai $300{ }^{\circ} \mathrm{C}$ selama 20 menit supaya lapisan karbon menempel sempurna pada kaca konduktif ITO dan tidak mudah hilang.

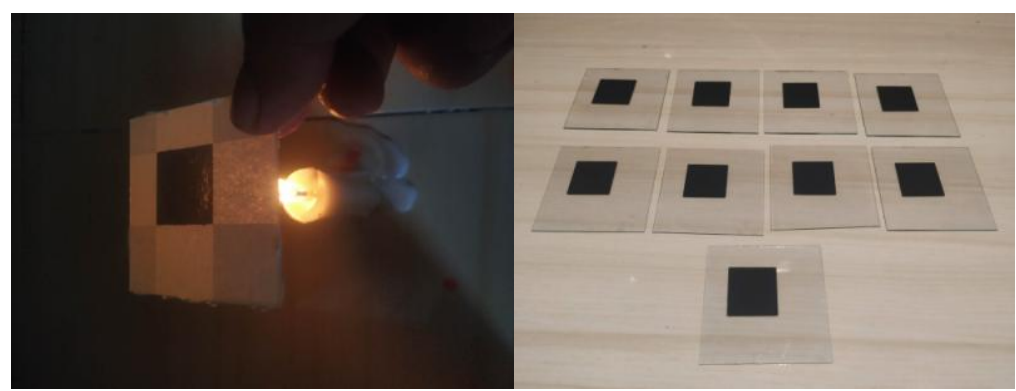

Gambar 2. Proses pembuatan katalis

Setelah katalis sudah jadi, kemudian diisi dengan elektrolit pada daerah yang telah ditentukan tersebut kemudian sandwich DSSC dirakit sampai prototype DSSC siap diuji.

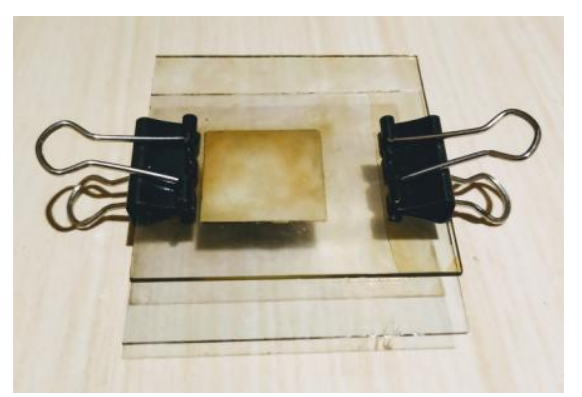

Gambar 3. Prototype DSSC 


\section{HASIL DAN PEMBAHASAN}

\subsection{Pengujian Spectrophotometer $U V$-Vis}

Hasil pengujian absorbansi ekstrak pucuk daun ungu dengan variasi lama perendaman (12, 24, 36 jam) dengan pelarut alkohol (96\%) yang diuji menggunakan alat spectrophotometer $u v$-vis pada rentang panjang gelombang $200-800 \mathrm{~nm}$ dapat ditunjukkan pada gambar dibawah.

Pada gambar 4, variasi lama perendaman 12 jam ekstrak pucuk daun ungu terdapat puncak tertinggi pada panjang gelombang $666 \mathrm{~nm}$ dengan nilai puncak absorbansi sebesar 1,8 dengan warna komplementer pada rentang panjang gelombang tersebut adalah warna hijau kebiruan.

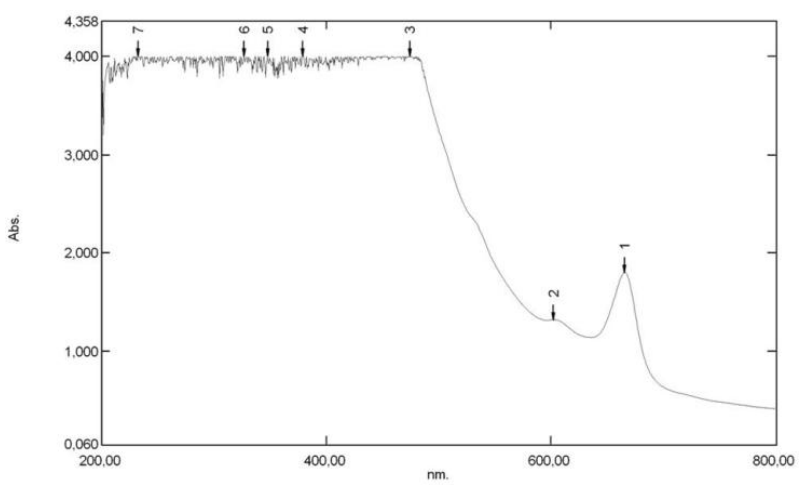

Gambar 4. Absorbansi lama perendaman 12 jam

Variasi perendaman 24 jam gambar 5 dibawah bisa dilihat hasil grafik $u v$-vis ekstrak pucuk daun ungu terdapat puncak tertinggi pada panjang gelombang $665 \mathrm{~nm}$ dengan nilai puncak absorbansi sebesar 2,2 yang dimana memiliki nilai lebih tinggi bila dibandingkan dengan variasi lama perendaman 12 jam.

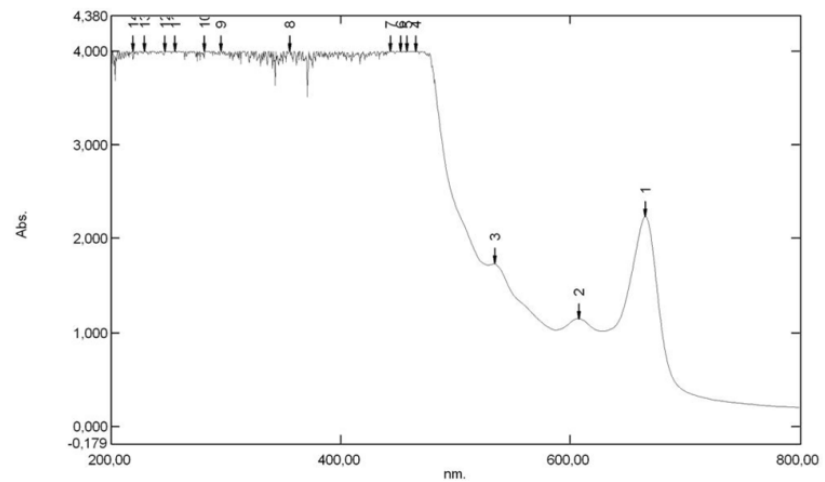

Gambar 5. Absorbansi lama perendaman 24 jam

Variasi lama perendaman 36 jam terlihat pada gambar 6 merupakan dengan nilai absorbansi tertinggi bila dibandingkan dengan variasi lama perendaman 12 jam dan 24 jam. Nilai absorbansi tertinggi yang didapat dari variasi lama perendaman 36 jam adalah 2,6 pada rentang panjang gelombang $666 \mathrm{~nm}$. 


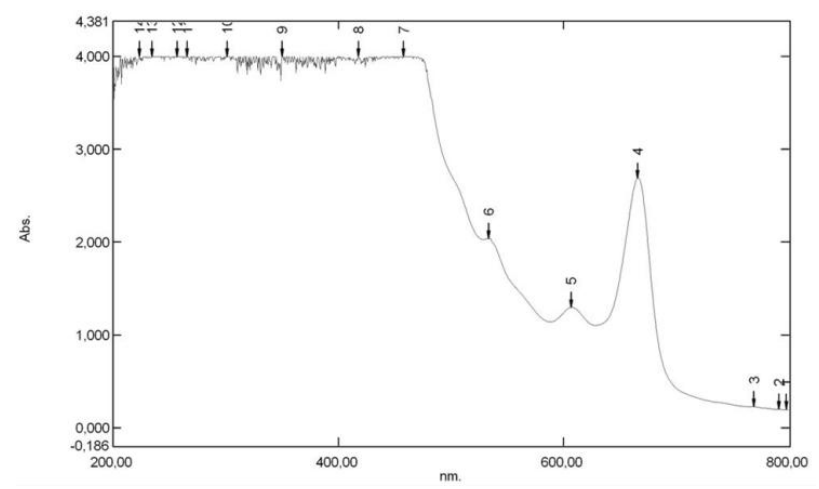

Gambar 6. Absorbansi lama perendaman 36 jam

Dalam penelitian yang telah dilakukan ini, puncak absorbansi atau daya serap maksimum dari ketiga variasi lama perendaman $(12,24$ dan 36 jam) diperoleh pada rentang panjang gelombang 665 - $666 \mathrm{~nm}$ yang dimana warna komplementer atau warna yang terlihat pada rentang panjang gelombang tersebut adalah warna hijau kebiruan.

\subsection{Pengujian Dye Sensitized Solar Cell}

Hasil seluruh data yang diperoleh, dapat dipastikan bahwa variasi lama perendaman ekstrak pucuk daun ungu 36 jam yang memiliki nilai tegangan yang paling tinggi bila dibandingkan dengan ketiga variasi. Nilai tegangan yang paling rendah adalah variasi lama perendaman 12 jam, 24 jam memiliki nilai diantara variasi lama perendaman 12 jam dan 36 jam. Berikut dibawah ini gambar grafik perbandingan nilai tegangan diantara ketiga variasi lama perendaman.

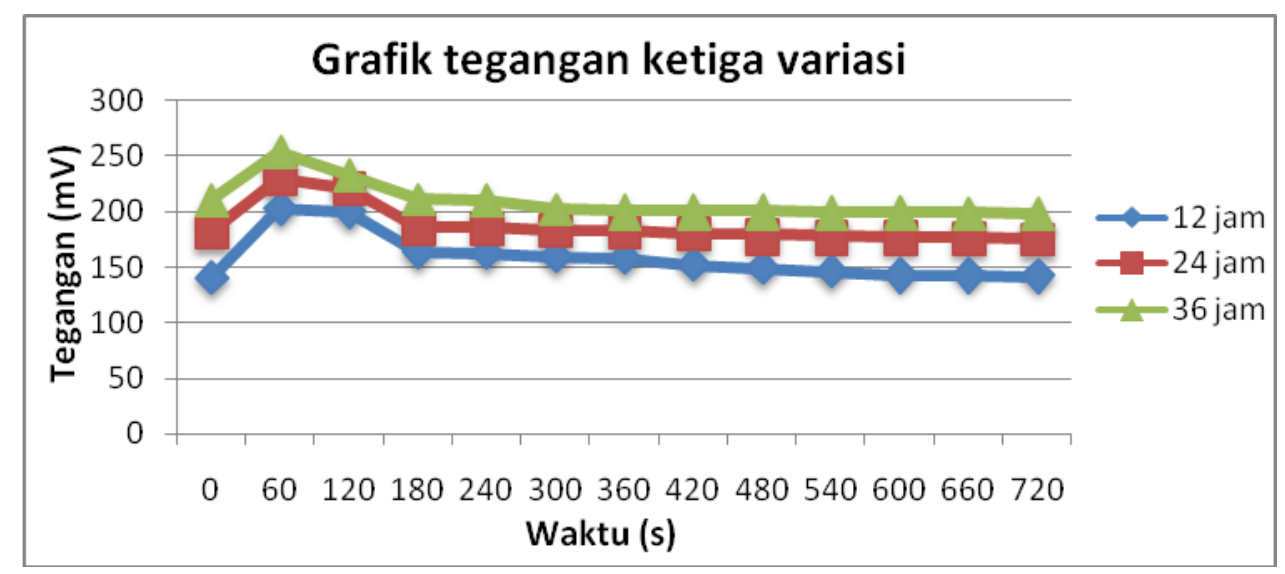

Gambar 7. Hasil pengambilan data ketiga variasi

Gambar 4 grafik perbandingan tegangan $(\mathrm{mV})$ ketiga variasi lama perendaman diatas dapat dilihat pada detik ke 60 dan 120 memperoleh nilai tegangan yang paling tinggi bila dibandingkan dengan waktu yang lainnya, hal ini dikarenakan pada penelitian ini daya absorb cahaya dan eksitasi dye maksimum dari $d s s c$ terletak pada waktu tersebut. Daya absorb dan eksitasi dye maksimum pada waktu tertentu didapat karena beberapa faktor diantaranya adalah tebal lapisan $\mathrm{TiO}_{2}$, konsentrasi larutan dan komposisi elektrolit. Jadi tidak semua penelitian akan mendapatkan daya absorb maksimum di waktu yang sama. Kemudian terjadi penurunan secara perlahan karena disebabkan oleh terjadinya degradasi elektrolit akibat terpapar cahaya dan panas yang bersumber dari lampu halogen 500 watt sebagai sumber cahaya yang implikasinya pada performansi dye sensitized solar cell. 


\section{SIMPULAN}

Berdasarkan hasil penelitian yang telah dilakukan, dapat ditarik kesimpulan bahwa pengaruh lama perendaman ekstrak pucuk daun ungu terhadap besaran tegangan yang dihasilkan dye sensitized solar cell memperoleh nilai tegangan yang tertinggi pada variasi lama perendaman 36 jam dengan nilai tegangan maksimum sebesar $254 \mathrm{mV}$ diikuti variasi lama perendaman 24 jam dengan nilai tegangan maksimum sebesar $230 \mathrm{mV}$, sedangkan variasi lama perendaman 12 jam memperoleh nilai tegangan paling rendah dengan nilai tegangan maksimum yang didapat sebesar $202 \mathrm{mV}$. Hasil nilai tegangan tersebut membuktikan bahwa variasi lama perendaman berpengaruh terhadap besaran tegangan yang mampu dihasilkan dye sensitized solar cell dengan ekstrak pucuk daun ungu.

\section{DAFTAR PUSTAKA}

[1] Hardeli., Dye Sensitized Solar Cell (DSSC) Berbasis Nanopori TiO2 Menggunakan Antosianin dari Berbagai Sumber Alami, Padang: Universitas Negeri Padang, 2013.

[2] Hikmah, Irmayatul., Pengaruh Penggunaan Gel-Electrolyte pada Prototipe Dye Sensitized Solar Cell (DSSC) berbasis TiO2 Nanopartikel dengan Ekstrak Murbei (Morus) sebagai Dye Sensitizer pada Substrat Kaca ITO, Surabaya: Institut Teknologi Sepuluh November, 2015.

[3] Nasukhah, Ana Thoyyibatun., Fabrikasi dan Karakterisasi Dye Sensitized Solar Cell (DSSC) dengan Menggunakan Ekstraksi Daging Buah Naga Merah (Hylocereus Polyrhizus) Sebagai Dye Sensitizer, Surabaya: Institut Teknologi Sepuluh November, 2012.

[4] Niski K, Biaunik., Pengaruh Penggunaan Gel-Electrolyte pada prototipe Dye Sensitized Solar Cell (DSSC) berbasis TiO2 Orde Nano Menggunakan Kulit Manggis Sebagai Dye Sensitizer, Surabaya: Institut Teknologi Sepuluh November, 2013.

[5] Septina, Wilman., Pembuatan Prototipe Solar Cell Murah dengan Bahan OrganikInorganik (Dye-sensitized Solar Cell), Bandung: Institut Teknologi Bandung, 2007.

[6] Subodro, Rohmat., Preparasi Elektrolit Sebagai Penstransfer Elektron pada Dye Sensitized Solar Cell (DSSC), Surakarta: Universitas Nahdlatul Ulama, 2016.

[7] Sukandarrumidi., Zadrak Kotta, Herry., Energi Terbarukan (Konsep Dasar Menuju Kemandirian Energi), Yogyakarta: Gadjah Mada University Press, 2013.

[8] Supranto, H., Teknologi Tenaga Surya, Yogyakarta: Global Pustaka Utama, 2015. 